\title{
THE FRONTIERS OF GRAECO-ROMAN RELIGIONS: GREEKS AND NON-GREEKS FROM A RELIGIOUS POINT OF VIEW
}

\section{Elena MuñIz Grijalvo}

Ancient Greeks seemed to be very concerned about who was Greek and who was not. At least, this is what we can infer from the great number of literary sources which dealt with the topic in one way or another. From Herodotus' Histories to, say, Tatian's Address to the Greeks (to give just one example of extremely opposite genres and aims), the frontier of Greekness was an important issue not only to the Greek mind, but also to the minds of other intellectuals from all over the oikouméne. However, Greekness was rarely systematically defined. The features of Greekness could be found in all forms of art, and covered areas from descent and language to more general ways of life. ${ }^{1}$

In this general picture religion played a key role, or, to be more precise, some religious aspects did. In the fifth century BC Herodotus wrote "so that things done by man not be forgotten in time, and that great and marvellous deeds, some displayed by the Hellenes, some by the barbarians, not lose their glory" (1.1). His approach to these two large groups, "Hellenes" and "barbarians", set a kind of agenda for those intending to describe new peoples. Among the categories that could be explored when dealing with a foreign people, religion occupied a privileged position. Herodotus focused on a handful of religious aspects to explain the distance between they-barbarians and we-Greeks. The result was not a clear picture of what Greek religion actually was, nor even of what religion meant for Herodotus. It was more a way of establishing the limits of Greek religion with respect to non-Greek peoples, in order to make the intellectual frontiers of the Greek world explicit.

As we will see, the ethnographical categories drawn by Herodotus proved to be lasting. Authors repeatedly tried to set the limits of the Greek world by focusing on quite similar subjects to describe other peoples. However, this continuity in the ethnographical religious approach did

${ }^{1}$ Well-known definitions of Greekness are Herodotus 8.144.3; Isocrates, Panegyricus 50; Dionysius of Halicarnassus 1.89.4; Dio Chrysostom 38.46. 
not mean that Greek religion was always the same, nor (and this is my point here) that the frontier of Greek religion was always set at the same place. The aim of this paper is to analyse how religion was used as a way of constructing different limits for the concept of Greekness. After a brief sketch of Herodotus' work as a starting point, I will focus on Strabo's Geography, firstly to show how he broadened the limits of Greek religion, so that it could be understood as "Graeco-Roman religion" instead, and secondly to show how the device was intended to set frontiers not only between Greeks and barbarians, but also between Greeks (or GraecoRomans) and non-Greeks within the Roman Empire.

Analysis of religion in Herodotus is becoming increasingly frequent in studies of his work. ${ }^{2}$ This is not surprising as the amount of religious data concerning not only the foreign peoples Herodotus describes, but also the Greeks themselves, is indeed remarkable. However, what we read in Herodotus is not an accurate picture of what Greek religion was actually like. No matter how much we read into it, ${ }^{3}$ he had no intention of doing so. As we have seen, he was merely trying to offer his audience an account of the deeds of Greeks and barbarians alike, and of the causes which led to the Persian wars. To achieve his goal, he considered it necessary to digress, focusing on the different peoples which had to do with either the barbarians (i.e. Persians) or the Greeks. The result is, as has been pointed out, a "patterned display provided by the range of cultures", in which Greece is not to be understood without barbarians, and vice versa. ${ }^{4}$

${ }^{2}$ Works including analysis of religion in Herodotus are: G. Lachenaud, Mythologies, religion et philosophie de l'histoire dans Herodote (Lille 1978); E. Hall, Inventing the Barbarian (Oxford 1991); S. Scullion, "Herodotus and Greek Religion", in C. DewaldJ. Marincola (eds.), The Cambridge Companion to Herodotus (Cambridge 2006), 192208; W. Burkert, "Herodot als Historiker fremder Religionen", in G. Nenci-O. Reverdin (eds.), Hérodote et les peuples non-Grecs (Genève 1990), 1-32; P. Cartledge, "Ancient and modern contestations of Hellenism", Bulletin Institute Classical Studies 40 (1995), 75-82; J. Redfield, "Herodotus the tourist", Classical Philology 8o (1985), 97-118. Specifically about religion in Herodotus: F. Mora, Religione e religioni nelle Storie di Erodoto (Milano 1986); J. Gould, "Herodotus and religion", in S. Hornblower (ed.), Greek Historiography (Oxford 1994), 91-106; T. Harrison, Divinity and History. The religion of Herodotus (Oxford 2000); J.D. Mikalson, "Religion in Herodotus", in E.J. Bakker-I.J.F. de JongH. van Wees (eds.), Brill's Companion to Herodotus (Leiden-Boston 2002); J.D. Mikalson, Herodotus and Religion in the Persian Wars (Chapel Hill 2003).

${ }^{3}$ And no matter how optimistic one chooses to be, as is the case with Mikalson 2003, op. cit. (n. 2), 6, who claims that "his Histories (...) may reasonably be claimed to be the best and richest single source for Greek religion as it was practised in the classical period".

${ }^{4}$ Redfield 1985, op. cit (n. 2), 106. 
Herodotus conceived the world as a system formed by the combination of peoples who were different from each other. A conscious effort to describe the constituents of his system can be found in his work, although he always focuses on what made the difference between them.

This is probably why Herodotus concentrated on certain matters and not on others, including when referring to religion. One of the easiest ways to underline the differences between two peoples is to describe what is patently obvious: their customs, what they do, especially what they do as a people and in public, and in the religious domain this means rituals. Herodotus' concern about ritual probably had a lot to do with this. ${ }^{5}$ In addition, of all the rituals, sacrifice is what he commented on most extensively.

The two richest descriptions of sacrifice are those of Persians and Egyptians. In both cases, but especially in Persian sacrifices, he chooses to center on what was definitely non-Greek. And thus he says explicitly that Persians "do not build altars or kindle fire, employ libations, or music, or fillets, or barley meal" (1.132.1), and continues to explain how "to pray for blessings for (oneself) alone is not lawful for the sacrificer" (1.132.2); or that "no sacrifice can be offered without a Magus" (1.132.3).

There is also a similarity in his description of Egyptian sacrifices. After dwelling at large on how "they instituted customs and laws contrary for the most part to those of the rest of mankind" (2.35.1), he gives examples of some bizarre Egyptian habits. Finally, he gets to religion, where special attention is paid to sacrifice and the way of killing and preparing the animal to be consumed: "they cut its throat, and having done so sever the head from the body. They flay the carcass of the victim, then invoke many curses on its head, which they carry away. Where there is a market, and Greek traders in it, the head is taken to the market and sold; where there are no Greeks, it is thrown into the river" (2.39.1-2).

As a rule, it seems that when Herodotus commented on a ritual, it was because there was often a Greek reference that was clearly different from the foreign one. ${ }^{6}$ The opposite may also be true: it seems that he

\footnotetext{
${ }^{5}$ We will probably never know to what extent his real concept of religious things had to do only with ritual. This is an important issue, which will not to be dealt with here. But I think that we should be a bit more cautious than Gould 1994, op. cit. (n. 2), 102, when he observes "how strikingly it (Herodotus' work) underlines for us the extent to which he and, one might guess, the majority of Greeks, defined their own religion to themselves and understood its significance largely in ritual terms".

${ }^{6}$ This is what may explain that, in his descriptions of other sacrifices, Herodotus stresses such things as the way of slaughtering the victims. When he describes Scythian
} 
brings up details about Greek religion because they explicitly show the differences between two peoples (every piece of information about Greek religion, therefore, should be considered in this light). But essentially the difference was not so great. To his mind, what characterised the Greeks or any other people was not that they had different customs, but that they went about them in different ways. As Scheid has observed, ancient authors thought that "everywhere people made sacrifices, prayers, and vows, celebrated sacred games, and built sanctuaries (...) But one thing made the difference between the religions of the world: the governing rules, those small details, choices, and postures which gave each system its originality". "Herodotus was therefore prepared to admit that the realm of religion was common to all civilised people: ${ }^{8}$ in his words "I believe that all men are equally knowledgeable about (the gods)" (2.3.2).

Consequently, no signs of superiority will be found in Herodotus regarding Greek religion. Admittedly, his work shows his deep pride in being Greek: "from old times the Hellenic stock has always been distinguished from foreign by its greater cleverness and its freedom from silly foolishness" (1.60.3). But religion had little to do with this. As has been observed, Herodotus' implicit aim "was to promote not Greek ethnic triumphalism but Greek ethno-political solidarity". "To achieve this, it was not necessary for Greek rituals to be older or better than the others: they just had to be felt as Greek.

The sense of belonging to a common political unit could be reinforced if people shared "the shrines of gods and the sacrifices", as the Athenians claimed when they wished to underline their Greekness to the rest of the Hellenes. ${ }^{10}$ As long as this bond was strong enough, Herodotus did

sacrifice, he chooses to underline that the sacrificer "throwing a noose around the beast's neck, he thrusts in a stick and twists it and so strangles the victim, lighting no fire nor offering the first-fruits, nor pouring any libation; and having strangled and skinned the beast, he sets about cooking it" (4.60.2). If Scythians strangle their victims, the Tauri "strike the victim on the head with a club" (4.103.1), and the Lybian nomads "wring the victim's neck" (4.188.1).

7 J. Scheid, "Graeco Ritu: A typically Roman way of honoring the gods", Harvard Studies in Classical Philology 97 (1995).

8 "Barbarians" were not necessarily uncivilised people for Herodotus: under this rubric very different grades of civilisation were included, from the Persians or the Egyptians, who were more civilised than the Greeks in some respects, to the remote peoples who lived outside the limits of civilisation. Interestingly, Herodotus does not record any religious custom of the latter.

${ }_{9}$ Cartlegde 1995, op. cit (n. 2), 82.

10 8.144.2. Similar claims about what the Greeks shared or what may be labelled as Greek religion may be found in Isocrates, Panegyricus 50 or Demosthenes, Philippics 3.32. 
not mind acknowledging that Greek rituals were not original, that there were older and higher forms of religion, or even that the Greeks had copied a great number of their habits from foreign peoples. Moreover, his complete lack of nationalism in this respect allowed him to present religious imitation as positive and typical of civilised people. Only the Scythians (those barbarians) would bother to reject foreign rituals, as they did when their fellow countryman, Anacharsis, dared to celebrate the feast of the Mother of the Gods in the Greek way, and the Scythian king "shot an arrow at him and killed him" (4.76.5).

Civilised people tended instead to adopt and develop foreign customs, when these were clearly superior. That is what the Greeks did, especially with respect to Egyptian religion. ${ }^{11}$ In his long description of Egyptian customs, Herodotus admits that not only had the names of Greek gods been imported from the Nile (2.50.1), but also Greek rituals (2.51.1), or those "practices called Orphic and Bacchic, but in fact Egyptian and Pythagorean" (2.81.2), or even highly Greek customs such as "that rite of Demeter, which the Greeks call Thesmophoria (...) The daughters of Danaus were those who brought this rite out of Egypt and taught it to the Pelasgian women" (2.171.2-3).

To sum up, not only was Greek religion in Herodotus conceived as a common possession of all those who called themselves Greek, but also as a recipient of foreign wisdom. It had been formed by the addition of the indigenous (the pre-Greek), with a great deal of Pelasgian customs, in addition to other definitely foreign names and rituals, in a sort of centripetal process which culminated in the formation of what the Greeks of the fifth century вс regarded as "their" religion. The frontiers of Greek religion in Herodotus were, therefore, easy to cross.

Things were very different when, more than four hundred years later, Strabo wrote his Geography, a work devoted to "the activities of statesmen and commanders but also as regards knowledge both of the heavens and of things on land and sea, animals, plants, fruits, and everything else to be seen in various regions" (1.1). Strabo thought that geographical science had "a bearing on the life and the needs of rulers" (1.18), so he conceived his work as a tool for those "men of exalted stations in life" (1.23). As was the case with Herodotus (but for very different reasons), his

${ }^{11}$ Although Greeks were not only subdued to the superior Egyptian religion, they also adopted "the robe and aegis of the images of Athena [which] were copied by the Greeks from the Libyan women" (4.189.1). 
task included a comprehensive description of a wide range of lands and peoples. Following what was by that time a long ethnographical tradition, he turned to the same categories which had been in use since classical times. However, at this point all similarities come to an end: neither imperial times nor Strabo's agenda were the same. In what follows, my aim is to show how the Roman empire had a profound impact on Strabo's suggestions on the frontiers of Greek religion.

At first sight not a lot had changed. Strabo continued to understand the oikouméne as a compound of two basic types of people: Greeks and barbarians. ${ }^{12}$ His work was deeply hellenocentric, as was only natural for a scholar well-trained in Greek literary and philosophical traditions. ${ }^{13}$ In addition, his description of the limits of the world and the characteristics of the peoples who lived out there rested upon tradition, even though he was well aware of political changes. ${ }^{14}$ In his eyes barbarians were unsocial, wild, and in general able to perform the most extreme reversals of Greek customs. And this meant not only innocent customs (as my fellow countrymen, the Cantabrians, who "bathe with urine which they have aged in cisterns, and wash their teeth with it, both they and their wives" (3.4.16)), but also the perversion of all that was sacred among the Greeks.

As was the case with Herodotus, Strabo's main concern when dealing with the religion of other peoples was ritual and, more specifically, sacrifice. Sacrifice was probably what distinguished more clearly the barbarians from the Greeks from a religious point of view. Some barbarians performed human sacrifices, such as the Cimbri, who, after killing the victim, "would beat on the hides that were stretched over the wickerbodies of the wagons and in this way produce an unearthly noise" (7.2.3); or the Albanians, who trampled the corpses of their victims (11.4.7), or the Lusitanians, who cut off one of the hands (3.3.6). However, the most

12 In this he differed from other authors such as Dionysus of Halicarnassus, Cicero and Quintilianus, who preferred to explain the world as divided into barbarians, Greeks and Romans; or those who proposed different divisions, such as Eratosthenes, who spoke of civilised people $v s$. bad people. See E. Almagor, "Who is a barbarian? The barbarians in the ethnological and cultural taxonomies of Strabo", in D. Dueck-H. Lindsay-S. Pothecary (eds.), Strabo's cultural geography. The making of a kolossourgia (Cambridge-New York 2005), 42-55.

13 Strabo's intellectual background in D. Dueck, Strabo of Amassia: A Greek man of letters in Augustan Rome (London-New York 2000), $31 \mathrm{ff}$. I have found this and Dueck et al. (eds.) 2005, op. cit (n. 12), especially useful. For a full bibliography on Strabo, see Sarah Pothecary's excellent webpage: http://strabo.ca.

${ }^{14}$ Dueck 200o, op. cit. (n. 13), 45. 
barbaric of all for Strabo was the Scythians, who not only killed human people, but "eat their flesh, and use their skulls as drinking-cups" (7.3.7).

However, being a barbarian did not necessarily mean going to the extreme of human sacrifice. Strabo could easily tell a Greek from a barbarian by merely describing what he considered as oddities in the sacrificial process. As in Herodotus, there are a lot of examples of these oddities, attributed always to peoples who were culturally removed from true civilization. Capadocians, for instance, "do not sacrifice victims with a sword either, but with a kind of tree-trunk" (15.3.15); Indian priests do not wear garlands, nor burn incense or pour out libations, "neither do they cut the throat of the victim, but strangle it" (15.1.54). ${ }^{15}$

To highlight the distance between Greeks and non-Greeks, therefore, Strabo based his theories on traditional categories of analysis, the very ones we have seen used by Herodotus. But, unlike Herodotus, it is quite interesting to note that Strabo focuses on sacrifice to mark the frontiers between civilised and non-civilised people. As we saw, Herodotus had commented in detail on Persian and Egyptian rituals. From the reading of those passages it is easy to conclude what was non-Greek. On the other hand, Persian or Egyptian rituals were in no way presented as inferior. Things were quite different for Strabo. Dealing with the same subjects as Herodotus, he managed to draw a very different picture of the inhabited world, in which for example the way a people performed sacrifice might be interpreted as one of the frontiers between civilization on the one hand, and the rest of the world on the other. If we take into account that Strabo was drawing a map of the world intended to be useful to the leaders of the Roman empire, ${ }^{16}$ the implicit message becomes clearer: those who sacrifice as we Greeks, may be regarded as civilised, and vice versa.

As a result, sacrifice continued to be a significant feature of Greek identity in Strabo's work, just as it was in Herodotus. What had changed were the effects of being Greek, and even more so, who the Greeks were in Strabo's eyes. Referring to among other things religion, Strabo was suggesting that the Greeks deserved a special position in the Roman Empire, because they were the real civilised people within it. Accordingly, being Greek ceased to be (as it was for Herodotus) just one of the many ethnic and political units in the oikouméne. It became a core identity, and not everybody could claim to be part of it.

15 Other examples are the Derbices (11.11.8) or the Lusitanians (3.3.6).

$161.18 ; 1.23$. 
Firstly, Strabo's Geography contained a wide range of arguments to support the exclusivity and superiority of the Greeks. As we will see presently, most of the arguments were religious. Secondly, we will see how Greek religious history was reinterpreted and how, in Strabo's eyes, it ceased to be a recipient of foreign traditions to become quite the opposite: a land that had irradiated its religious ways to the rest of the world and offered a canonical interpretation of religion suitable for the leaders of the empire. Thirdly, and more importantly, Strabo altered the frontiers of religious Greekness to make room for new and very useful fellow community members: the Romans. We will see some examples of a new religious identity, which rather than 'Greek' should be labelled "GraecoRoman".

Let us firstly look at how Greek religion was presented as superior to others. Unlike Herodotus, who was ready to marvel at foreign temples, ${ }^{17}$ Strabo ignored almost all the non-Greek sanctuaries. ${ }^{18}$ However, in his books dedicated to the description of Greece the opposite is true: even the humblest altar in Greece deserved his full attention. Maybe the best way to summarise the general impression he wanted to convey to his readers about Greece lies in one of the statements he makes about Attica. Admitting that there are too many remarkable things to describe in it, he resorts to the words of Hegesias, who had also recognized that he was unable to point them all out one by one, and preferred to sum them up by saying that "Attica is the possession of the gods, who seized it as a sanctuary for themselves, and of the ancestral heroes" $(11.1,16)$.

Like Attica, Strabo's Greece was a kind of sanctuary. Throughout Greece countless sacred spots whether extravagant or modest could be found: altars, sanctuaries, statues, and so on. No matter how small or unimportant a place had become, it could still claim the glory of being the seat of some heroic or divine cult, which dignified it and made it different. His main interests lay naturally in the most famous festivals, such as the Olympian Games, which were famous worldwide and remained famous even after the oracle of the Olympian Zeus had failed to respond: "the glory of the temple persisted nonetheless, and it received all that increase of fame of which we know, on account both of the festal assembly and

17 See J. Lightfoot (ed.), On the Syrian goddess (Oxford 2003), 179-180, who remarks that Herodotus uses the word hagios to refer to foreign temples.

${ }_{18}$ Except for the large sanctuaries in Asia Minor, which attracted his attention because he probably knew many of them at first hand, see for example Strabo, Geographika 12.2.3, which is a description of the temple of Ma Comana. 
of the Olympian Games, in which the prize was a crown and which were regarded as sacred, the greatest games in the world" (8.3.30).

However, not only did Olympia attract Strabo's attention, but he also took time to comment mainly on religious things related to much smaller and less important places, unknown to anyone outside Greece, such as a place "between Lepreum and the Annius", where "the temple of the Samian Poseidon"19 is (8.3.16), or a settlement called "Samicum, where is the most highly revered temple of the Samian Poseidon" (8.3.13). These places were unlikely to be of any importance from a strategic point of view. There was no point in informing the Romans of their existence, unless intending to draw their attention to the sacredness of Greece as a whole. Every mountain, every valley, every town, no matter how small or insignificant they were, was (or had been) either the birthplace of a god, or a place where a hero had stayed, or the location of a Homeric episode. ${ }^{20}$

This leads us directly to another of Strabo's most obvious goals. Apart from giving a general impression of the holiness of Greece, an impression which was not shared by any of the inhabited world, he focused on the antiquity and the continuity of religious traditions as strong points in a claim for Greek superiority. ${ }^{21}$ With this in mind, the fact that a ritual had been performed in the same way since ancient times was indeed a good argument, and therefore he mentioned this at every opportunity. A good example is Strabo's account of the pan-Ionian sacrifices paid to the Heliconian Poseidon: "the sea was raised by an earthquake and it submerged Helicê, and also the temple of the Heliconian Poseidon, whom the Ionians worship even to this day, offering there the Pan-Ionian sacrifices" (7.7.2). In this way he drew a line of continuity which linked his own era to archaic times, in the assumption that the Greek way of doing things had always been the same, and that there was only one possible way of performing rituals, if they were going to be labelled as "Greek".22

\footnotetext{
19 See Pausanias 5.5.5-6: Pausanias explains that there was no sanctuary in his days, except for one which belonged to Demeter.

${ }^{20}$ Some examples are 8.3 .16 ; 9.1.21-22; 9.2.13; 9.2.36; 9.3.2; 9.3.13.

${ }^{21}$ Also Dionysus of Halicarnassus was of the same opinion: national rites do not change, unless the nation has been defeated by others (see F. Prescendi, Décrire et comprendre le sacrifice (Stuttgart 2007), 60).

${ }^{22}$ For instance, speaking about mountaineers in Iberia, he explains that "they also offer hecatombs of each kind, after the Greek fashion-as Pindar himself says, 'to sacrifice a hundred of every kind'" (3.3.7).
} 
However, his strongest argument in this respect had to do with the fact that the father of religion, Homer, was Greek. It has been pointed out that Strabo devoted much of his work to Homer and, in general, to poetic discussions. ${ }^{23}$ The reasons why "the poet" (as he likes to call him) was so important to him, have been very well explained by Dueck in her recent work about Strabo as "a Greek man of letters": ${ }^{24}$ first and foremost, because of his scholarly orientation, which had been highly influenced by his teachers and which made of him a Stoic. ${ }^{25}$ In my view, a further reason may be added to this. Strabo argues that Homer "alone has seen, or else he alone has shown, the likenesses of the gods" (8.3.30), and therefore it was he who inspired sculptors or poets when they were physically representing the gods:

It is related of Pheidias that, when Panaenus asked him after what model he was going to make the likeness of Zeus, he replied that he was going to make it after the likeness set forth by Homer in these words "Cronion spake, and nodded assent with his dark brows, and then the ambrosial locks flowed streaming from the lord's immortal head, and he caused great Olympus to quake". A noble description indeed, as appears not only from the "brows" but from the other details in the passage, because the poet provokes our imagination to conceive the picture of a mighty personage and a mighty power worthy of a Zeus, just as he does in the case of Hera, at the same time preserving what is appropriate in each ... $\quad 8.3 .30$

Homer's authority was therefore undisputed, and the fact that he was Greek and that his works were at the heart of Greek religion, was the main argument for supporting the idea of Greek superiority, at least in the religious domain. In fact, Strabo was not the only one who made use of this powerful argument. Other authors wishing to underline the exceptional dignity and antiquity of Greek religion referred back to Homer ${ }^{26}$ before and, in particular, after Strabo's time.

${ }^{23}$ For an overview of works dealing with Strabo's use of Homer, see A.M. Biraschi, "Strabone e Omero. Aspetti della tradizione omerica nella descrizione del Peloponneso", in A.M. Biraschi (ed.), Strabone e la Grecia (Perugia 1994), 25-57.

${ }^{24}$ Dueck 2000, op. cit. (n. 12), 38-39.

${ }^{25}$ But see Biraschi 1994, op. cit. (n. 23), 27, who remarks that "se è vero che per la piena 'riabilitazione' della poesia omerica si erano battuti grossi esponenti del pensiero stoico quali Cratere e Posidonio (...) è però anche vero che Strabone, nella sua difesa del Poeta, segue una propria prospettiva che sembra avere essenzialmente come scopo quello di giustificare la piena validità della presenza omerica in un'opera di geografia universale".

${ }^{26}$ See for example Dio Chrysostom, Oration XII passim, or Plutarch, On the Pythian Responses, passim. 
Not everybody in Strabo's eyes could boast about being Greek. Who the Greeks were is quite a controversial issue, especially during the Roman Empire. Of course there is no simple answer to the question-it depends basically on the interests of whoever uses the term. The answer ranges from a very broad definition of Greekness, like the one proposed by Fergus Millar, including "those places which were the location of the named recurrent agones-musical, theatres and athletic contests-which were so important a feature of the communal life of Greek cities", and that were "attested as far south as Gaza and Bostra, but no further; at Damascus but not at Palmyra; and up to, but not across, the Euphrates,",7 to the all too limited definition of Greekness in Pausanias, for whom all Greek things (the famous pantà tà helleniká) ${ }^{28}$ were contained within the limits of the Greek peninsula - and not even throughout. ${ }^{29}$

What seems to be a well-attested tendency throughout the Roman period is that Greek intellectuals established narrower limits on Hellenism. ${ }^{30}$ It is only normal that it should be this way. If the Greeks were to benefit from Roman benevolence, Greekness could not include the countless people who claimed to be living a Greek way of life. So paradoxically the number of Greeks, which had constantly increased from Alexandrian times on, declined for many Greek writers. In my view, religious arguments were decisive for this more restrictive definition of Greekness. ${ }^{31}$

Strabo's Geography was one of the first works where the definition of Greekness is definitely more limited than it was in Herodotus. In his Histories, Herodotus described the process of the formation of "the Greeks", who in his eyes were a blend of the peoples who lived in Greece from ancestral times, and the Pelasgians. ${ }^{32}$ Greekness, and even Greek

${ }^{27}$ F. Millar, The Roman Near East 31 BC-AD 337 (Cambridge, Mass.-London 1993), 234.

${ }^{28}$ Pausanias 1.26.4.

${ }^{29}$ C. Bearzot, "La nozione di koinós in Pausania", in D. Knoepfler-M.D. Piérart, (eds.), Éditer, traduire, commenter Pausanias en l'an 2000 (Genève 2001); M. Jost, "Unité et diversité: La Grèce de Pausanias", Revue des Études Grecques 119 (2006), 568-587.

${ }^{30}$ See for instance D. Braund, "Greeks and Barbarians: The Black Sea Region and Hellenism under the Early Empire", in S.E. Alcock (ed.), The Early Roman Empire in the East (Oxford 1997), 121-136.

${ }^{31}$ Or maybe not so paradoxically, if we consider that identity is most insistently defined where it is most at risk (T. Whitmarsh, "The harvest of wisdom: landscape, description, and identity in the Heroikos", in E.B. Aitken-J.K.B. Maclean (eds.), Philostratus's Heroikos: Religion and Cultural Identity in the Third Century CE (Leiden 2005), 241).

32 2.51.2. 
religion, was for him a mixture of foreign ideas, names and rituals. ${ }^{33}$ This view was completely unacceptable for Strabo. In fact, he attributes no foreign origins to any of the religious features that he explains. Moreover, he even suggests that it was the Greeks who had exported their rituals and had themselves provoked a blend of cultures, but always outside the Greek world. Therefore, if Herodotus described the formation of Greek religion as a kind of centripetal process, ${ }^{34}$ Strabo did exactly the opposite, alluding to a centrifugal movement, which spread a pure Greek religion all over the Mediterranean.

The exportation of Greek gods and rituals took place during the Greek hegemony of Europe, which was prior to the Macedonian and the Roman leadership, as Strabo proudly reminds us. ${ }^{35}$ It was probably at that time when many barbarian nations adopted certain Greek rituals, which they continued to perform to Strabo's time. Thus, the Iberian mountaineers offered "hecatombs of each kind, after the Greek fashion" (3.3.7); the Iberians had been taught by the Massiliotes "the sacred rites of the Ephesian Artemis, as practiced in the fatherland, so that they sacrifice by the Greek ritual" (4.1.5); and even the Romans "offered a sacrifice to (Heracles) after the Greek ritual, which is still to this day kept up in honour of Heracles" (5.3.3).$^{36}$ It is quite interesting to note that Herodotus registered only two similar cases of religious transfer, but both of them were the result of private initiative and were aborted soon afterwards. ${ }^{37}$

In a way, the religious colonization of the Mediterranean by the Greeks set an important basis for future colonization or conquests. However, Strabo did not stop at that. Not only had the barbarians adopted some Greek ways and thus could be more easily understood by the Greeks or their like, but Greek religious categories could also be applied to describe and to analyze barbarian customs which, had it not been for the Greeks, would have been completely incomprehensible. Strabo went to the trouble of explaining rituals already familiar to the Romans as if they were Greeks: "the Sabini (...) vowed (just as some of the Greeks do) to dedicate everything that was produced that year" (5.4.12).

\footnotetext{
33 Ibidem.

${ }^{34}$ In classical times, as was observed by J. Rudhardt, "De l'attitude des Grecs a l'égard des religions étrangeres", Revue de l'Histoire des Religions 109.3 (1992), 238, the Greeks did not export their gods.

35 2.5.26.

${ }^{36}$ About the Roman sacrifice to Herakles graeco ritu, see Scheid's illuminating article: Scheid 1995, op. cit. (n. 7).

${ }^{37}$ Herodotus 4.76.
} 
The implicit idea here is that for the Romans the job of the pacification and unification of the Mediterranean had already been carried out by the Greeks, who had either left a unified world (in cultural and religious terms) behind them, or had at least provided the intellectual tools necessary to understand all barbarian customs. This is exactly what Strabo was aiming for. In his effort to offer the leaders of the empire a useful guide to ruling their dominions, Strabo presented a religious ethnography, which could be understood by the Greeks and the Romans alike.

To achieve this goal, he used different techniques. One of them was, as we have seen, to identify barbarian rituals with their Greek equivalents. However, the most powerful device was his general approach to religious customs. Until the development of anthropological science well into the nineteenth century, so-called ethnographers had always tended to choose and comment on those foreign habits that they could understand; that is, on the customs that were parallel to their own. Today we are perfectly aware that this approach prevents us from obtaining any real knowledge of foreign peoples. However, it is also true that this kind of reductionist and distorted approach, which focuses only on what may be understandable for the readers, helps to bring foreigners much closer to the people in question. Coming back to Strabo, even when he was trying to separate the barbarians as much as possible from civilized people, even when he was describing how the Scythians drank wine in the skulls of their victims, in a way he was bringing the Scythians (the barbarians) closer to his audience. After all, human sacrifice was nothing more than a kind of sacrifice. The choice of familiar topics was therefore essential to help everybody understand him and the Mediterranean.

Yet another further device was used by Strabo in this attempt to bring the subjects of the empire closer to his masters. It consisted in presenting foreign customs that were in his eyes similar to typically Greek ones, as common to the whole human race. In a couple of long passages, which were characteristic of Stoic scholars, he maintained that certain attitudes were not only common to Greeks and barbarians, but were also "natural". To give but one example, when the Jews were harassing the land of Syria and Phoenicia,

... still they had respect for their acropolis, since they did not loathe it as the seat of tyranny, but honoured and revered it as a holy place. For this is natural; and it is common to the Greeks and to the barbarians; for, being members of states, they live under common mandates; for otherwise it would be impossible for the mass of people in any country to do one and the same thing in harmony with one another, which is precisely 
what life in a free state means, or in any other way to live a common life. And the mandates are twofold; for they come either from gods or from men; and the ancients, at least, held those from the gods in greater honour and veneration.

16.2.37-38

The typically Greek explanation of civil and religious order contained in this passage was therefore presented as the reason for alien religious behaviour. Herodotus had also explained certain religious features as universal and common to all mankind. ${ }^{38}$ But Strabo was more clearly applying Greek mental categories to the analyses of these attitudes, which can be considered as "only natural". ${ }^{9}$ There is an illuminating passage in Plutarch that reveals the same approach to religion. In his oration against the epicurean Colotes, Plutarch describes what he regards as the religious behaviour common to all human groups:

In your travels you may come upon cities without walls, writing, king, houses or property, doing without currency, having no notion of a theatre or a gymnasium; but a city without holy places or gods, without any observance of prayers, oaths, oracles, sacrifices for blessings received or rites to avert evils, no traveller has ever seen or will ever see. No, I think a city might rather be formed without the ground it stands on than a government, once you remove all religion from under it, get itself established or once established survive.

$1125 \mathrm{e}$

As we can see, not only did Plutarch consider it impossible to rule men without resorting to religion, but he also made what he regards as the only possible rituals that may be performed in a polis explicit: prayers, oaths, oracles, sacrifices, and so on. In a word, all those things that represented Greek civic religion.

When applied to the description of a wide variety of alien people, Greek religious categories acted as a powerful resource that helped to "domesticate" barbarians. And thus we are back to the outset of Strabo's Geography: Strabo was avowedly working for the Romans, providing them with tools to rule a huge empire. Not only did he physically describe the empire, but he also offered an intellectual approach, which would help the Romans in their task of ruling the Mediterranean. Of course,

\footnotetext{
${ }^{38}$ See above, page 136.

39 Another good example of the same may be found in 10.3.9. As regards the etymology of the word "Curetes", Strabo adds: "Now this is common both to the Greeks and to the barbarians, to perform their sacred rites in connection with the relaxation of a festival, these rites being performed sometimes with religious frenzy, sometimes without it; sometimes with music, sometimes not; and sometimes in secret, sometimes openly. And it is in accordance with the dictates of nature that this should be so, for ...".
} 
this approach would be much more easily understood and accepted if Greek religion was felt not only as Greek, but as Roman too, that is, if the Romans felt that Strabo's perceptions were common to the only civilized peoples in the empire, the Greeks and the Romans. So Strabo devised a new religious identity, which ceased to be merely Greek and might be felt as "Graeco-Roman".

Consequently, we come to my third and final point. The creation of this new identity meant a further benefit for the Greeks: as partners of the Romans in the key realm of religion, they could claim for a privileged position within the empire. To this end, Strabo got down to work vigorously. All over the Geography, Greeks were presented as superior to Romans in many respects: certainly not in political achievements, but decidedly so in cultural deeds, so much so, that he dares to describe the situation of the south of Italy in his own day as "completely barbarized", 40 just because the Greeks had left it in the hands of other (incidentally, very romanized) peoples. But he went even further. He portrayed the ancient Romans as people who did not care for learning or education. However, this was going to change: as soon as the Romans came into contact with the Greeks, they started to pay attention to what the true virtues of rulers were:

The Romans too, in ancient times, when carrying on war with savage tribes, needed no training of this kind, but from the time that they began to have dealings with more civilised tribes and races, they applied themselves to this training also, and so established themselves as lords of all.

9.2 .2

If the Geography were to be read by any Roman leader, in my opinion Strabo was indeed being very bold. However, his approach to religion could make this superiority complex more bearable. He used religious topics to create stronger bonds between Greeks and Romans. This is evident in his description of the Roman colony of Nicopolis. After explaining how Augustus had re-founded the city, he goes on to describe the present appearance of Nicopolis as a thoroughly Greek city, full of sacred spots, just as he envisaged the rest of Greece: ${ }^{41}$

Nicopolis is populous, and its numbers are increasing daily, since it has not only a considerable territory and the adornment taken from the spoils of the battle, but also, in its suburbs, the thoroughly equipped sacred precinct-one part of it being in a sacred grove that contains a gymnasium and a stadium for the celebration of the quinquennial games, the other

40 6.1.2.

41 See above, page 140. 
part being on the hill that is sacred to Apollo and lies above the grove. These games - the Actia, sacred to Actian Apollo-have been designated as Olympian and they are superintended by the Lacedaemonians. $\quad$ 7.7.6

Nicopolis was founded by Augustus and therefore Roman, but it kept and enhanced the Greek religious flavour, thus creating a perfect mixture of identities. This idea was launched in a more explicit way when Strabo spoke about "our usages", referring to the Greek religious customs that had been adopted and imposed by the Romans to other peoples:

The heads of enemies of high repute (...) they (the Gallic peoples) used to embalm in cedar-oil and exhibit to strangers, and they would not deign to give them back even for a ransom of an equal weight of gold. But the Romans put a stop to these customs, as well as to all those connected with the sacrifices and divinations that are opposed to our usages.

In conclusion, presenting the Greeks as clearly superior in cultural and religious terms was no doubt an important strategy for negotiating the position of the Greeks within the Roman empire. Strabo and others used it repeatedly to the end of the Roman Empire. However, it was equally important to create a common religious ground on which a new GraecoRoman identity could be based. Strabo's Geography, a work devised to explain the world to the Romans, was a perfect chance to build a religious frontier for the empire, which placed their Greek subjects at the center of the Roman universe.

Sevilla, December 2009 